\title{
USING MEDIA TO TEACH DIFFERENT LEARNING STYLE IN X AND XII GRADE OF VOCATIONAL SCHOOL OF MEDICAL NUSANTARA PAMEKASAN
}

\author{
${ }^{1}$ devikurniati76959@gmail.com (Devi Kurniati) \\ ellyimrotulkhulufiah1996@gmail.com (Elly Imrotul Khulufiah) \\ 3evasusanti109@gmail.com (Eva Susanti) \\ 4junainahhabibi@gmail.com (Junainah) \\ 5rhicasilvia96@gmail.com (Rhica Silvia Wijayanti)
}

\begin{abstract}
Absract
The purpose of this article is knowing the use of media to teach different learning style of student in Vocational School of Medical Nusantara Pamekasan. In this article, the researcher got the data by doing direct interview with one of the English teacher in that school. Based on the data, this article explain about the use of media to teach students with differet learning style.
\end{abstract}

Keywords: language teaching, media, learning style

\section{Introduction}

Nowadays, education is not left behind from the development of science and technology which has brought significant changes to the all dimensions of human life, include education. Related with education world, the use of media is needed to be used and mastered by teacher. So that they can deliver the subject matter to the students in good and effective way.

In the relationship with learning process, media is part of the learning itself. Learning is a process in individual can changes students attitude, behavior and thinking. ${ }^{1}$ In the process of learning, students have their own way to understand the material they learn that called learning style. Learning style might be thought of as "cognitive, affective, and physiological traits that are relatively stable indicators of how learner preceive, interact with, and respond to the learning environment. ${ }^{2}$ The learning style influences how we like to learn and how we learn best so that in our way of interacting with other people and our style of thinking can clasifying in the learning style. There are three types of learning style, that are visual, auditory and kinesthetic. In teaching learning process, teacher will find the different characteristics and learning style of students, so the teachers are striven to make the student understand the materials although they are different learning style.

In deliver materials, teachers need media to help them in teaching. There some definitions of media. Brown state that media is the carriers information between sources

\footnotetext{
${ }^{1}$ Dadang Sunendar, Strategi Pembelajaran Bahasa, (Bandung:PT Remaja Rosda Karya), p.1

${ }^{2}$ H. Douglass Brown. Principles of Language Learning and Teaching Fourth Edition. Addison Wesley Longman,Inc, p.114
} 
and receiver. ${ }^{3}$ Media is any instrument that is to help students comprehend english easily. ${ }^{4}$ According to aims instructional or contains the purposes of teaching. ${ }^{5}$ Rossi dan Breidle suggested that learning media are all tools and materials that can be used for educational purposes such as radio, television, books, newspapers magazines, etc. ${ }^{6}$ So, simply learning media can be described as a media in it contains the elements of information or message is instructional and can be used in a teaching process. Like that Gagne and Briggs (1975) said that learning media is a media that bring the messages or information that

Currently the use of instructional media has not been widely applied in the teaching and learning process in schools. Most educators prefer to teach with learning model that is still centered on the teacher. The teacher acts as only the source of learning, presenting lesson with lecture models, solving problems, with very little or even no supporting media. Only tachers are actively speaking while the student are passive. If students can not a accept the lesson, they can not understand the materials too. There is no media tha can inspire students to learn. In other words, the learning process is very boring. Thus the learning process becomes ineffective. So the purpose of learning is less than optimal. Consequently the result of students are still classified as less.

From all the problems that occur, the use of media in teaching learning process is very important because it can improve the spirit of students and help the process of learning activities in teaching. In addition to helping in motivating students media also help in facilitating students in capturing material easily that presented by teachers. As we know that students have different way and characteristics in study, the teacher can utilize any kinds of media. With the media also students will not feel bored in the ongoing learning activities. Teacher play an important role in improving motivation and learning outcomes obtained by students and how the teachers try to use media of learning both modern learning media and even simple natural learning media. Therefore , in this article we raised the tittle "The Use of Media to Teach Different Learning Style of Student"

Dealing with the study above then the written going to dig all information about something appear in his mind, knowing about how the use of media to teach students especially vocational school's students with different learning style teaching learning process, knowing about how the teacher strategy in taking care their sudent who has different style learning.

\footnotetext{
${ }^{3}$ Robert Heinich, Sharon E. Maldino, James D.Russel, Michael Molenda. Instructional Technology and Media for Learning Eight Edition. Pearson:New Jerseyp. P.15

${ }^{4}$ Eva Nikmatul Rabbianty, Handout Practicum's Intructional Media, Tadris Bahasa Inggris Jurusan Tarbiyah STAIN Pamekasan, (june,2010), page 2.

${ }^{5} \mathrm{http} / / /$ belajarbahasainggrisku.com/2014/06/media-pembelajaran-bahasa-inggris-pengertian-tujuan-dancontoh.html

${ }^{6}$ Prof . Dr. H. Wina Sanjaya, M.pd, Perencanaan Dan Desain Sistem Pembelajaran.(Jakarta: Kencana Prenada Media Group.2010).Page 204
} 
Answering all the problem above, the writer used descriptive qualitative research, it is a research that focus on words or sentences other than numeric ${ }^{7}$, in this case interview to the subject of the study by using unstructured interview. The writer freely to ask the subject of the study itself, seen the writer as the key instrument. Finally, Miles and Hubberman's method of analysis used to discuss the data ${ }^{8}$.

\section{Theoretical Review}

\section{Learning Style}

Over many years and through many research projects and detailed observation of the way we communicate, three particular learing-visual, auditory and kinesthetic-have been identified. ${ }^{9}$

Learning style is the way and technique that use by student to learn and process the information. Selecting and use appropriate learning style help student learn faster and easier. Most experts agree that there are three basic learning style. Student may have one learning style or more than one learning style.

Might be thought of as "cognitive, affective, and physiological traits that are relatively stable indicators of how learner preceive, interact with, and respond to the learning environment. Among the three learning styles, there are differences among visual style, auditory and kinesthetic. Each student has a learning style and between students with each other is different style.

Basically, learning style are devided into three part, they are as follow: ${ }^{10}$

a. Visual style

Visual learner prefer to learn by seeing. They have good visual recall and prefer information to be presented visually, in the form of diagrams, graphs, maps, posters and displays, for example. They often use hand movement when describing or recalling events or objets and have a tendency to look upward when thinking or recalling information.

b. Auditory style

Auditory learner prefer to learn by listening. They have good auditory memory and benefit from discussion, lectures, interviewing, hearing stories audio tapes.

c. Kinesthetic style

Kinesthetic learner prefer to learn by doing, they are good at recalling events and associate feelings or physical experiences with memory. They enjoy physical activity, field trips, manipulating obects and other practical, first-hand experience. Kinesthetic learner usually have difficulty to keep still and need regular breaks in classroom activities. ${ }^{11}$

\footnotetext{
7 John W. Creswell, Research Design: Qualitative, Quantitative, and Mixed Methods Approaches, 4th Edition, 4th edition (Thousand Oaks: SAGE Publications, Inc, 2013); John W. Creswell, Qualitative Inquiry and Research Design: Choosing Among Five Approaches, Third Edition edition (Los Angeles: SAGE Publications, Inc, 2012); Vicki L. Plano Clark and John W. Creswell, Understanding Research: A Consumer's Guide, 1 edition (Upper Saddle River, N.J: Pearson, 2009); Christine Daymon and Immy Holloway, Metode Riset Kualitatif (PT Mizan Publika, 2008), Rizabuana Ismail, Metode Penelitian Kualitatif (USUpress, 2009), Conny R. Semiawan, Metode Penelitian Kualitatif (Grasindo, 2007), . ${ }^{8}$ Miles and Hubberman, Analisis Data Kualitatif, ....

${ }^{9}$ Alan Pritchard.Way of Learning. (New York: Routledge. 2009) P.44

${ }^{10}$ Ibid. page. 44-45

${ }^{11}$ Alan Pritcard, , ways of learning. (New York: Routledge. 2009). P. 45
} 
Acording to Gavin Reid, there are benefit about Visual and Auditory. ${ }^{12}$

1. Visual learners would benefit from:

- The use of visual diagram.

- Use of video, flasheards, charts and maps.

- Practicing visualising words and ideas.

- Writing out notes for frequent and quick visual scan and review.

2. Auditory learner would benefit from:

- Sounding out words in reading.

- Verbal instructions.

- The use of tapes

- Rehearsing information, repeating it many times to get the sound.

\section{Media}

Media is the singular from of medium that mean as a means of communication. ${ }^{13}$ According to Heinic in Arsyad's book, media is a tool to deliver information from sourcer to receiver. ${ }^{14}$

A medium (plural, media) is a means of communication and source of information. In general, the media have benefit: ${ }^{15}$ moreover the teacher teacher usually use technology as one of media in teaching. Technology can be a powerful tool for helping teachers to achieve different cognitive goals. ${ }^{16}$ Example include video, television, diagrams, printed materials, computer programs, and instruction. These are considered instructional media when they provide messages with an instructional purpose. The purpose of media is to facilitate communication and learning. ${ }^{17}$

According to Djamarah, based on their characteristic, there three kind of media: ${ }^{18}$

a. Audio media.

It is the media which has content of messages that is only received through the sense of hearing. Audio can convey a verbal message (spoken language) and non-verbal message (the sounds and vocalisation).

b. Visual media.

It is the media which involves the sense of vision,, such as picture, graph, diagram, chart etc.

c. Audio-visual media.

It is the media which involves the sense of of vision and hearing at once, such as video, movie and tv program. This audio-visual media will bw subject of this study. Thus it will be explained specifically later.

\section{Language Teaching}

a. Grammar Translation Method

\footnotetext{
${ }^{12}$ Gavin Reid. Learning Stye and Inclusion (New Delhi: Paul Chapman Publishing,2015), p:121

${ }^{13}$ Sri Anitah, Media Pembelajaran, (Surakarta: Yuma Pustaka, 2010), p. 4

${ }^{14}$ Azhar Arsyad, Media Pembelajaran, (Surakarta: PT Raja Grafindo Persada, 2011), p. 4

${ }^{15}$ Rudi Susilana and Cepi Riana, Media Pembelajaran (Bandung: CV Wacana Prima, 2007) page. 6.

${ }^{16}$ David A Jacobsen, Methods for Teaching, (Yogyakarta: Pustaka Pelajar, 2009) page. 108.

${ }^{17}$ Sharon E. Smaldino, Instructional Technology and Media for Learning, (Ohio: Prentice Hall, 2010), page. 9

${ }^{18}$ Djamarah, Syaiful Bahri and Aswan Zain, Strategi Belajar Mengajar, (Jakarta: PT. Rineka Cipta, 2006), page. 15
} 
The Grammar-Translation Method is not new. It has had different names, but it has been used by language teacher s for many years. At one time it was called the Classical Method since it was first used in the teaching of the classical languages, Latin and Greek (Chastain 1988). The purpose of helping students read a nd appreciate foreign language literature. It was also hoped that, through the study of the grammar of the ta rget language, students would become more familiar with the grammar of their native language and that this familiarity would help them speak and write their native language better. Finally, it was thought that foreign language learning would help students grow intellectually; it was recognized that students would probably never use the target language, but the mental exercise of learning it would he beneficial anyway. ${ }^{19}$ Based on the statement above, Grammar translation method (GTM) emphasizes the teaching of the second language grammar, its principle techniques is translation from and into the target language. And practice, reading and writing are the major focus; little or no sistematic attention is paid to speaking or listening.

Prator and Celce-Murcia 1979:3 listed the major characteristics of Grammar Translation: ${ }^{20}$

1. Classes are taught in the mother tongue, with little active use the target language.

2. Much vocabulary is taught in the form of lists of isolated words.

3. Long, elaborate explanations of the intricacies of grammar are given.

4. Grammar provides the rules for putting words together, and instruction often focuses on the form and inflection of words.

5. Reading of difficult classical text is begun early.

6. Little attention is paid to the content of the texts, which are treated as exercises in grammatical analysis.

7. Often the only drills are exercises in translating disconnected sentences form the target language into the mother tongue.

8. Little or no attention is given to pronounciation.

b. Audio-Lingual Method

The Audio-Lingual Method, like the Direct Method we have just examined, is also an oral-based approach. However, it is very different in that rather than emphasizing vocabulary acquisition through exposure to its use in situations, the Audio-Lingual Method drills students in the use of grammatical sentence patterns. ${ }^{21}$

The characteristics of the ALM may be summed up in the following list (adapted from Prator and Celce-Murcia 1979): ${ }^{22}$

1. New material is presented in dialogue form.

2. There is denpendence on mimicry, memorization of set phrases, and over-learning.

3. Structures are sequenced by means of contrastive analysis and tought one at a time.

4. Structural patterns are taught using repetitive drills.

\footnotetext{
${ }^{19}$ Diane Larsen-Freeman, Techniques and Principles in Language, (Oxford: Oxford University press, 2000), page. 11

${ }^{20}$ H. Douglas Brown, Teaching by Principles an Interactive Approach to Language Pedagogy,( ), page. 18

${ }^{21}$ Diane Larsen-Freeman, Techniques and Principles in Language, (Oxford: Oxford University press, 2000), p. 35

${ }^{22}$ H. Douglas Brown, Teaching by principles an Interactive Approach to Language Pedagogy,( ), p. 22
} 
5. There is little or no grammatical explanation. Grammar is taught by inductive analogy rather than by deductive explanation.

6. Vocabulary is strictly limited and learned in context.

7. There is much use of tapes, language labs, and visual aids.

8. Great importance is attached to pronunciation.

9. Very little use of the mother tongue by teachers is permitted.

10. Successfull responses are immediately reinforced.

11. There is a great effort to get students to produce error-free utterances.

12. There is a tendency to manipulate language and disregard content.

\section{c. Silent Way}

Silent way is characterized by a problem-solving approach. Develops independence and autonomy and encourages students to cooperate with each other.

a. Learning is facilitated if the learner discovers or creates rather than remembers and repeats what is to be learned.

b. Learning is facilitated by accompanying (mediating) physical objects).

c. Learning is facilitated by problem solving the material to be learned.

Although people did lean languages through the Audio-Lingual Method (and indeed it is still practiced today), one problem with it was students inability to readily transfer the habits they had mastered in the classroom to communicative use outside it.

The emphasis on human cognition led to the establishment of the Cognitive Approach (Celce-Murcia 1991). Rather than simply being responsive to stimuli in the environment, learners were seen to be much more actively responsible for their own learning. ${ }^{23}$

\section{Focus of The Study}

1. Is there any obstacles during the teaching learning process in the $\mathrm{X}$ grade of Senior High School of Medical Nusantara Pamekasan?

2. How the teacher overcome the visual, auditory and kinesthetic students in the $X$ grade of Senior High of Medical School Nusantara?

3. Do the teacher use media in teaching learning process? What kinds of media used by the teacher?

\section{Method}

Research method is general strategy follow in gathering and analyzing the data necessary for answering the question at hand. ${ }^{24}$ In this case, the reasercher uses qualitative approach to give description about how to teach the student which has different characters in the X and XII Vocational School of Medical Nusantara Pamekasan. While, the kind of research that is used by the researcher is descriptive research.

\footnotetext{
${ }^{23}$ Diane Larsen-Freeman, Techniques and Principles in Language, (Oxford: Oxford University press, 2000), p. 53

${ }^{24}$ Donall Ary, Introduction to Research in Education. (USA: WadsworthThomson Learning,2002), p.25
} 
The reason of the researcher is to know the method or strategy of the teacher when she teaches English in Senior High of Medical Nusantara Pamekasan. The reason is the researcher can ask directly the response of teacher about how to teach the student that has dofferent learning style, such as visual learners, audio learners and kinesthetic learners. Descriptive research is data that is presented by using some words without numerical form. That is to observe the teacher's response to teach English by using media.

Source of data is the subject which the data got. ${ }^{25}$ Lofland also stated that the main source of data in qualitative are some words and actions, document and another are as primary source of data. In this research the researcher use actions by coming the informant directly to get information. The location is in teacher's home. Why the researcher chooses this locations is because of the researcher is easy to ask directly. So that, it know how far the teacher use method in learning style. To get information completely, the researcher need instrument. There are many kinds of instrument such as observation, interview and documentation. However, the researcher use interview. Interview is conversation with certain purpose that is done by the interviewer (someone who gives the questions) to the interview (someone who will answer the question). In this case, the interviewers include the teacher who will be the subject of research.

The types of interview that is use by the researcher is standardized and unstandardized. Standardized interview is interview which the interviewer determines the problems and the question by herself and the question are also prepare before. ${ }^{26}$

\section{Finding}

In the finding of researcher, the interviewer discuss about teaching learning process in Senior High School of Medical Nusantara Pamekasan. There are four points that will be explain by the interviewer. They are: the obstacles that happened during the teaching learning process, how the teacher overcome the obstacles, the use of media in teaching learning process and the kinds of media that the teacher use.

The interviewer conduct an interview with an English teacher of $\mathrm{X}$ grade of Senior High School of Media Nusantara Pamekasan to obtain the data. The interview has been done on September, 30th 2017.

Furthermore, there are some obstacles that happened during the teaching learning process in X grade of Senior High School of Medical Nusantara Pamekasan. They would be explained by the interviewer as follows:

\section{Some obstacles that happened during the process of teaching learning in Senior High School of Medical Nusantara Pamekasan}

\footnotetext{
${ }^{25}$ Suharsimi Arikunto, Prosedur Penelitian:Suatu Pendekatan Praktik,(Jakarta: PT. Rineka Cipta,2010), p.172

${ }^{26}$ Esti,Ismawati. Metode penelitian pendidikan bahasa dan sastra.(surakarta: yuma pustaka,2011)p.97
} 
During the teaching learning process, the process is not always running well. There are many unpredictable situation and obstacles that can be happened in class. The English teacher of Senior High School of Medical Nusantara Pamekasan teach X and XII grade class. She found many different learning style of students in each class due to the different characteristics of the students. She said:

"Students in each class have different characteristics. There are the diligent student, the lazy one, uncommunicative and other different skills. The obstacles in class usually is just about the different characteristics of students itself. An obstacle is automatically happened, because the students is different. There are the naughty student, diligent student and the different skill of students become the obstacles for teacher when the teacher would to give the materials but the students can not accept it smoothly."

\section{Some ways and strategies used by the teacher to overcome the obstacles that happened during the teaching learning process}

In X and XII grade of Senior High School of Medical Nusantara Pamekasan, the english teacher teach different learning style and characteristics of student and it makes her quite confuse to decide what method that suitable with the material and the different characteristics of students. It is a problem that have to be resolved. So, the firstly teacher determine the learning style of the students. After the teacher know the learning style of the students, it makes her easier to choose the method and strategy in teaching learning process later. She state:

"Beeing a teacher not only think about how to deliver our knowledge but also think about what method that suitable with the different charateristic of students. The teacher has to know the students learning styles to decide the method they will use to teach. Sometimes teacher has already prepared materials and method to teach the class but sometimes it can be failed when the teacher think that all students are alike. That is wrong when teachers assume that all students are same learning styles and it can be a problems for the teachers itself . So, firstly the teacher has to identify the learning style of the students, who are included the visual, auditory, and kinesthetic students. Teacher must have their own notes about the students characteristics except the attendance list."

The teacher also say that teachers have to be crative in finding good strategy in order to the students can follow the lesson well. Because of she teach in medical school, she has to prapare the english material and added it with medical content.

\section{The use and the Kinds of Media that Used in Teaching Learning Process in $X$ and XII grade of Senior High School of Medical Nusantara Pamekasan}

Media are the carriers information between source and receivers. Usually teacher use any kinds of media in teaching learning process to make the students easier to understand what the teacher explain. For the teacher, teacher have to use media in teaching learning process. She state that:

"Teaching by using media is a must. It is not a choises or just a bid. Moreover nowadays is modern and digital era. Our school also provide the facilities such as wifi connection, so that the students can use their mobile phone during the lesson. Beside that, our school also provide LCD in each class, that are all we use. How to make the 
students interested,especially in language class. If the class is quiet, it is not the language class. Langage class have to speak up. So, using media is a must."

Media can help teacher easier to deliver the materials. There are any kinds of media that can be used in the class, no matter it is technological or just simple natural media in the class. The english teacher use some facilities that provided from the school. The school provide some facilities. They are LCD and projector in each class and also wifi connection. She said:

"Usually I use the projector, LCD and others. Sometimes anything in class can be the media, namely realia, the real thing in the class can be media, not only the technology. The simple natural things also can be a media."

The teacher added that sometimes whe the situsations did not support to use technological media in class, such as there is no electricity or there is something wrong with the media, teacher will use other real things in class. For example is the picture, blackboard, or the students itself. Then she will ask the students to describe something by using real thing arround the class, or just make conversation and practice it in front of the class.

\section{Discussion}

Based on the process of getting the datas then the writer going to explore the data taken from the subject of the study. Firstly, In knowing the learning style of the students, the teacher have to know what are the kinds of learning style itself. She state that :

"as we know that there are three types of learning style, visual learners who study by using visual sense, auditory learners who are more understanding the materials by using their hearing and the last is kinesthetic learners who have to do some movement or touch the subject or material so that they can understand what had been explain by the teacher."

Based on her statement above we know that the teacher understand with the learning style. The information gotten from the teacher about the learning style above, contradict with several experts that talking about it. The statement is in mutual accord with the statement of Jeremy Harmer that the kinds of learning style namely visual, auditory and kinesthetic learners. ${ }^{27}$

Then, in the following discussion is about what are the obstacles that happened during the teaching learning process, how the teacher overcome the obstacles, the use of media and what kinds of media used in the class.

1. Some obstacles that happened during the teaching leanrning process in $\mathrm{X}$ grade of Senior High School of Medical Nusantara Pamekasan.

\footnotetext{
${ }^{27}$ Jeremy harmer, How to Teach English,(Malaysia: Pearson Education Limited,2007), P.16
} 
As we know that in the process of teaching and learning, unpredictable thing and obstacles can be happened when the class ran. It can be from the students, teacher's preparation and others. In this case, the english teacher of X and XII grade of Senior High School of Medical Nusantara said that the obstacles in her teaching process is about facing students with different characteristics. Different characteristics means that each students have their own style in study, so if the the teacher just explain the materials without looking at the learning style of the students, they can be difficult to receive the materials.

The teacher also told us about the characteristics of the students. There are diligent student, naughty students even over active students although they are Senior High School's students. Almost the X grade students are more enthusiastic than the XII grade. So the teacher feel quite difficult to make students interested with the materials. Moreover the school is medical school which the subject concern in medical aspects.

2. Some ways and strategies used by the teacher to overcome the obstacles in teaching learning process.

The obstacles that happened during the process of teaching and learning is a problem that have to be resolved by the teacher. Sometimes teacher had prepared the preparation of teaching but it can be failed if the teacher assume that all students are alike. So, the teacher said that to overcome this problems, firstly she has to identify and know the characteristics and learning style of each students. Teacher must have their own notes about the student, who are include visual, auditory or kinesthetic students. Then teacher must prepare what she will present in class. It is include materials, method and also media that suitable with the material.

Based on the statement above, it is contradict with the theory of the first step of ASSURE model about analyze learner. The theory state that if the instuctional media and technology are to be used effectively, there must be a match between the characteristics of learners and the content of methods, media and materials. ${ }^{28}$

Teaching in the X and XII grade is quite different for the teacher because the X grade is more enthusiastic than the XII grade. So, to make the students interested with the materials, sometimes she use mix and match method, depend on the topic and situation. For example, when the situation of class begin boring, she will add games in the middle of learning process so that the students did not feel bored.

3. The use of Media and the kinds of Media that used in Teaching Learning Process in X and XII grade of Senior High School of Medical Nusantara Pamekasan

The use of media can help teacher to deliver the materials. So, the teacher must choose suitable media to build up and improve the skills of students. The media include technological media or just simple natural media.

The english teacher of X and XII grade of Senior High School of Medical Nusantara usually use the media that provide from the school. The school provide class

\footnotetext{
${ }^{28}$ Sharon E. Smaldino, Instructional Technology and Media for Learning, (Ohio: Prentice Hall, 2010), page. 9
} 
with LCD and projector in each class. The school also provide wifi connection so that in teaching lerning process, students can access an internet for study. The teacher allows students use their own mobile phone or laptop during the lesson if it is needed. In other situation, teacher also use natural media arround the class. For example like pictures, blackboard or the students itself. So whatever the situation, there is technological media or not, the class still can run well using any real thing that can be a media and it is called realia.

In applying the media, to make all students understand the materials although they are different learning style, teacher used media such as laptop that played video in the slide. Students asked to watch the video and make little e xplanation related with the video. The purpose is to make visual and auditory learners take attention to the video. While some students present in front of the class. The kinesthetics learners can get task to practice what had been seen in the video.

Other activities that teacher used is the the teacher ask student to make written conversation by imitating the model of chat appearence in social media. The teacher try to make students interested with the instruction from the students by follow what they liked but still focus on the materials.

Based on the explanation about the use of media above, most media that used by the teacher actually appropriate with the six basic types of media used in learning and instruction. ${ }^{29}$ They are text, audio (includes anything you can hear; a person's voice, music, mechanical sounds, etc), visuals (includes diagrams on a poster, drawing on a chalkboard, photograph, book, etc), motion media (include vidiotape, animation and so on), manipulatives, and people.

\section{REFERENCES}

Alan Pritchard.Way of Learning. (New York: Routledge. 2009

Azhar Arsyad, Media Pembelajaran Surakarta: PT Raja Grafindo Persada, 2011

Dadang Sunendar, Strategi Pembelajaran Bahasa, Bandung:PT Remaja Rosda Karya.

Diane Larsen-Freeman, Techniques and Principles in Language, (Oxford: Oxford University press, 2000

Djamarah, Syaiful Bahri and Aswan Zain, Strategi Belajar Mengajar, Jakarta: PT. Rineka Cipta, 2006

Donall Ary, Introduction to Research in Education. (USA: WadsworthThomson Learning,2002),

Eva Nikmatul Rabianti. 2009. Theory of Teaching and Learning. Stain Pamekasan Press Gavin Dudeney, Nicky Hockly. How to Teach English with Technology. Pearson Longman.

Gavin Reid. Learning Stye and Inclusion. New Delhi: Paul Chapman Publishing,2015

H. Douglass Brown. Principles of Language Learning and TeachingFourth Edition. Addison Wesley Longman,Inc.

\footnotetext{
${ }^{29}$ Sharon E. Smaldino, Instructional Technology and Media for Learning, (Ohio: Prentice Hall, 2010), page. 9
} 


\section{JURNAL ILMIAH BAHASA DAN SASTRA \\ Volume 5 Nomor 1 Tahun 2018 \\ eISSN : 25494155 - pISSN : 23557083}

Jeremy Harmer, 2007. How to Teach English China:Ocelot Publishing.

Pupuh Fathorrahman, M, Sobri Sutikno, Strategi Belajar Mengajar Melalui Penajaman Konsep Umum dan Konsep Islami

Robert Heinich, Sharon E. Maldino, James D.Russel, Michael Molenda. Instructional Technology and Media for Learning Eight Edition. Pearson:New Jersey

Sri Anitah, Media Pembelajaran. Surakarta: Yuma Pustaka, 2010

${ }^{1}$ David A Jacobsen, Methods for Teaching, (Yogyakarta: Pustaka Pelajar, 2009) page. 108.

Rudi Susilana and Cepi Riana, Media Pembelajaran (Bandung: CV Wacana Prima, 2007) page. 6 . 